\title{
Hydrogen sulfide reduces regional myocardial ischemia injury through protection of mitochondrial function
}

\author{
YING-HUA XIE ${ }^{1}$, NAN ZHANG ${ }^{1}$, LAN-FANG LI ${ }^{2}$, QIN-ZENG ZHANG ${ }^{2}$, LI-JUN XIE ${ }^{2}$, \\ HONG JIANG ${ }^{2}$, LI-PING LI ${ }^{2}$, NA HAO $^{2}$ and JIAN-XIN ZHANG ${ }^{1,2}$ \\ ${ }^{1}$ Department of Pharmacology, Hebei Medical University, Shijiazhuang, Hebei 050017; ${ }^{2}$ Department of Pharmacology, \\ Hebei Academy of Medical Sciences, Shijiazhuang, Hebei 050021, P.R. China
}

Received October 30, 2013; Accepted May 28, 2014

DOI: $10.3892 / \mathrm{mmr} .2014 .2391$

\begin{abstract}
Hydrogen sulfide $\left(\mathrm{H}_{2} \mathrm{~S}\right)$ is a signaling gasotransmitter, involved in various physiological and pathological processes. $\mathrm{H}_{2} \mathrm{~S}$-donating drugs have been tested to conjugate the beneficial effects of $\mathrm{H}_{2} \mathrm{~S}$ with other pharmaceutical properties. It has been shown that the endogenous cystathionine- $\gamma$-lyase $(\mathrm{CSE}) / \mathrm{H}_{2} \mathrm{~S}$ pathway participates in myocardial ischemia injury in isolated hearts in rats. The present study aimed to investigate the cytoprotective action of $\mathrm{H}_{2} \mathrm{~S}$ against acute myocardial ischemia injury in rats. Isolated rat hearts were perfused and subjected to ischemic conditions for $4 \mathrm{~h}$. The hearts were assigned to five groups: Sham, model, infarct plus low-dose ( $5 \mu \mathrm{mol} / \mathrm{l}) \mathrm{NaHS}$, infarct plus middle-dose $(10 \mu \mathrm{mol} / \mathrm{l}) \mathrm{NaHS}$ and infarct plus high-dose $(20 \mu \mathrm{mol} / \mathrm{l}) \mathrm{NaHS}$. The administration of NaHS enhanced the activity of CSE, increased the content of $\mathrm{H}_{2} \mathrm{~S}$ and reduced infarct volumes following myocardial ischemia injury. Furthermore, the administration of NaHS attenuated the injury to organelles (including the mitochondria, nucleus and myofilaments) by reducing lactate dehydrogenase activity, decreasing the level of mitochondrial malondialdehyde and increasing the activities of superoxide dismutase and glutathione peroxidase in the ischemic myocardial mitochondria. These protective effects of $\mathrm{H}_{2} \mathrm{~S}$ against myocardial ischemia injury appeared to be mediated by its antioxidant activities and the preservation of mitochondrial function.
\end{abstract}

\section{Introduction}

Cardiovascular diseases are the leading cause of mortality worldwide and their incidence is increasing concurrently with the development of society and changes in lifestyle (1). Ischemic heart disease, which can cause arrhythmia and

Correspondence to: Professor Jian-Xin Zhang, Department of Pharmacology, Hebei Medical University, Zhongshan East Road, Shijiazhuang, Hebei 050017, P.R. China

E-mail: zhangjx100@163.com

Key words: hydrogen sulfide, cardioprotection, ischemia, mitochondria, oxidative stress, rats myocardial infarction, is a current major focus of the cardiovascular pathologies (2) since it is projected that ischemic heart disease is likely to be the primary cause of mortality in the population by $2030(3,4)$. Despite advances in understanding the pathogenesis of this disease, current treatments for ischemic heart disease are not sufficient (5-7) and, therefore, the effective relief of the injury caused by myocardial ischemia is a priority in medical research. Coronary artery ligation is the most common method of establishing an acute myocardial ischemia model and is widely used in studies investigating the mechanisms of myocardial ischemia (8). The method of Langendorff isolated retrograde heart perfusion is a prominent experimental technique used in the field of cardiovascular research and provides stability, reliability and convenience $(9,10)$.

Hydrogen sulfide $\left(\mathrm{H}_{2} \mathrm{~S}\right)$ was the third endogenous signaling gasotransmitter to be identified, following nitric oxide (NO) and carbon monoxide (11-15). Endogenous $\mathrm{H}_{2} \mathrm{~S}$ is widely present in mammalian tissues and has numerous signaling functions, thus contributing to various physiological and pathological processes (16-21). It has been shown that $\mathrm{H}_{2} \mathrm{~S}$ can antagonize ischemic reperfusion injury and therefore exhibit cardioprotective effects (22-26). However, associations between $\mathrm{H}_{2} \mathrm{~S}$ and acute myocardial ischemia injury are less well established, and the mechanisms underlying the effects of $\mathrm{H}_{2} \mathrm{~S}$ remain unclear.

In this study, an acute myocardial ischemia injury rat model was established using the method of coronary artery ligation. The aim of this study was to observe whether $\mathrm{H}_{2} \mathrm{~S}$ could protect the hearts against ischemic injury and whether antioxidation was involved in the cardioprotection induced by $\mathrm{H}_{2} \mathrm{~S}$.

\section{Materials and methods}

Animals. Male Sprague Dawley rats, weighing 250-290 g, were provided by the Center of Experimental Animals of Hebei Province (Shijiazhuang, China). Rats were acclimated for one week, with standard rat chow and water provided ad libitum. All experimental protocols were approved by the Animal Care and Use Committee of Hebei Medical University (Shijiazhuang, China) and were performed in accordance with the Guidelines of Animal Experiments from the Committee 
of Medical Ethics, National Health Department of China (Beijing, China).

Myocardial ischemia injury. Coronary occlusion was performed as previously described (27). The rats were anesthetized with $10 \%$ chloral hydrate at $350 \mathrm{mg} / \mathrm{kg}$ via intraperitoneal injection. The heart was rapidly excised and washed with Krebs-Henseleit buffer (K-H buffer), then retrogradely perfused through the aorta at a constant pressure of $90 \mathrm{~cm} \mathrm{H}_{2} \mathrm{O}$ with $\mathrm{K}-\mathrm{H}$ buffer containing $6.91 \mathrm{~g} / 1 \mathrm{NaC}, 0.35 \mathrm{~g} / \mathrm{l}$ $\mathrm{KCl}, 0.265 \mathrm{~g} / 1 \mathrm{CaCl}_{2} \cdot 2 \mathrm{H}_{2} \mathrm{O}, 2.1 \mathrm{~g} / 1 \mathrm{NaHCO}_{3}, 2.2 \mathrm{~g} / 1$ glucose, $0.296 \mathrm{~g} / 1 \mathrm{MgSO}_{4} \bullet 7 \mathrm{H}_{2} \mathrm{O}$ and $0.1632 \mathrm{~g} / 1 \mathrm{KH}_{2} \mathrm{PO}_{4}(\mathrm{pH} 7.35-7.45$ when aerated with $95 \% \mathrm{O}_{2} / 5 \% \mathrm{CO}_{2}$ at $37^{\circ} \mathrm{C}$ ). The left anterior descending (LAD) coronary artery was occluded with a 6.0 -silk suture $2-3 \mathrm{~mm}$ from the tip of the left atrium, at the end of the stabilization period. Successful coronary occlusion was verified by the development of a pale color in the distal myocardium. Coronary flow rate $(\mathrm{CF})$ was measured by timed collection of the coronary effluent for $1 \mathrm{~min}$.

Drug preparation and experimental protocol. NaHS, 2,3,5-triphenyl tetrazolium and Evans-Blue were purchased from Sigma-Aldrich (St. Louis, MO, USA). Lactate dehydrogenase (LDH), mitochondrial malondialdehyde (MDA), superoxide dismutase (SOD) and glutathione peroxidase $\left(\right.$ GSH-P $\left.\mathrm{P}_{\mathrm{x}}\right)$ detection kits were purchased from Nanjing Jiancheng Bioengineering Institute (Nanjing, China). NaHS was dissolved in K-H buffer.

The animals were randomly assigned to five groups: i) Sham; ii) model; iii) infarct plus NaHS at a concentration of $5 \mu \mathrm{mol} / \mathrm{l}$; iv) infarct plus NaHS at a concentration of $10 \mu \mathrm{mol} / \mathrm{l}$; and v) infarct plus NaHS at a concentration of $20 \mu \mathrm{mol} / 1$. The three treatment groups were treated with the $\mathrm{H}_{2} \mathrm{~S}$-donor (NaHS) $2 \mathrm{~h}$ after the induction of ischemia. The LAD coronary artery was ligated for $4 \mathrm{~h}$ in the rats of the model and NaHS-treated groups, but the rats in the sham group were threaded without ligation. The sham and model groups were subjected to perfusion with normal perfusate, and the experimental groups were perfused with NaHS perfusate $2 \mathrm{~h}$ after ischemia $(5,10$ or $20 \mu \mathrm{mol} / 1$, accordingly).

Hemodynamics. A water-filled latex balloon was inserted via the left atrium into the left ventricle and was inflated to set a left ventricular end-diastolic pressure of between 6 and $8 \mathrm{mmHg}$ during the initial equilibration. This allowed monitoring of the left ventricular systolic pressure, the maximum velocity of left ventricular systolic pressure $\left(+\mathrm{dP} / \mathrm{dt}_{\max }\right)$ and the maximum velocity of left ventricular diastolic pressure $\left(-\mathrm{dP} / \mathrm{dt}_{\max }\right)$. The coronary effluent was collected to measure coronary flow rate (ml/min).

Tissue $\mathrm{H}_{2}$ S concentration. The tissue $\mathrm{H}_{2} \mathrm{~S}$ content was measured as described previously with modifications (24). Briefly, cardiac tissue was homogenized in a 10 -fold volume (w/v) of $50 \mathrm{mM}$ ice-cold potassium phosphate buffer $(\mathrm{pH}$ 6.8). The cardiac tissue homogenate was then mixed with $0.5 \mathrm{ml} 1 \%$ zinc acetate. A total of $0.5 \mathrm{ml} 20 \mathrm{mM} \mathrm{N}, \mathrm{N}$-dimethyl-p-phenylenediamine sulfate in $7.2 \mathrm{M} \mathrm{HCl}$ was subsequently added, immediately followed by the addition of $0.4 \mathrm{ml} 30 \mathrm{mM} \mathrm{FeCl}_{3}$ in $1.2 \mathrm{M}$ $\mathrm{HCl}$. Following $20 \mathrm{~min}$ incubation, $0.5 \mathrm{ml} 10 \%$ trichloroacetic acid was added to the reaction mixture prior to the addition of $2.5 \mathrm{ml}$ distilled water. The absorbance of the resulting solution at $670 \mathrm{~nm}$ was measured using a BioTek microplate reader (BioTek Instruments Inc., Winooski, VT, USA). The $\mathrm{H}_{2} \mathrm{~S}$ content was calculated against a calibration curve of NaHS, and the $\mathrm{H}_{2} \mathrm{~S}$ concentration was expressed as micromoles/gram protein.

Tissue cystathionine- $\gamma$-lyase (CSE) activity. The $\mathrm{H}_{2} \mathrm{~S}$ production rate was measured as a reflection of CSE activity (28). Myocardial tissue was homogenized in 1:10 (wt/vol) $50 \mathrm{mM}$ ice-cold potassium phosphate buffer ( $\mathrm{pH}$ 6.8). The subsequent reactions were performed in a $25-\mathrm{ml}$ Erlenmeyer flask. The reaction mixture $(1 \mathrm{ml})$ consisted of $100 \mathrm{mM}$ potassium phosphate buffer ( $\mathrm{pH}$ 7.4), $10 \mathrm{mM} \mathrm{L}$-cysteine, $2 \mathrm{mM}$ pyridoxal 5 -phosphate and $10 \%(\mathrm{w} / \mathrm{v})$ tissue homogenate. Trapping solution of $0.5 \mathrm{ml} 1 \%$ zinc acetate was added to a Cryovial ${ }^{\circledR}$ test tube in the flask, which was used as the center well, and a small piece of filter paper $\left(2.0 \times 2.5 \mathrm{~cm}^{2}\right)$ was used to increase the air/liquid contact surface. The flask was flushed with $\mathrm{N}_{2}$ prior to being sealed, and then was transferred from an ice bath to an agitated water bath at $37^{\circ} \mathrm{C}$ to initiate the reaction. After 90 min, the reaction was terminated with the addition of $0.5 \mathrm{ml} 50 \%$ trichloroacetic acid. The flask was incubated further for an hour at $37^{\circ} \mathrm{C}$ in order to completely trap the $\mathrm{H}_{2} \mathrm{~S}$ released from the mixture. The content of the center well was transferred to a test tube containing $3.6 \mathrm{ml}$ distilled water and $0.5 \mathrm{ml} 20 \mathrm{mM} \mathrm{N}, \mathrm{N}$-dimethyl-p-phenylenediamine sulfate in $7.2 \mathrm{M} \mathrm{HCl}$ was added immediately, followed by the addition of $0.4 \mathrm{ml} 30 \mathrm{mM} \mathrm{FeCl}_{3}$ in $1.2 \mathrm{M} \mathrm{HCl}$. After $20 \mathrm{~min}$, the absorbance of the resulting solution at $670 \mathrm{~nm}$ was measured with a BioTek microplate reader. The $\mathrm{H}_{2} \mathrm{~S}$ content was calculated against the calibration curve of NaHS. The $\mathrm{H}_{2} \mathrm{~S}$ production rates were expressed as nanomoles per milligram protein per minute.

Infarct size. Myocardial infarction was determined according to a previously described method (29). The heart was perfused with $1 \mathrm{ml} \mathrm{1 \%}$ Evans Blue to stain the non-ischemic tissue $4 \mathrm{~h}$ after ischemia and frozen for between 3 and $24 \mathrm{~h}$. Transverse sections $(2-\mathrm{mm})$ were incubated in $1 \%$ triphenyltetrazolium chloride in phosphate buffer $\left(\mathrm{pH} \mathrm{7.4)}\right.$ ) for $15 \mathrm{~min}$ at $37^{\circ} \mathrm{C}$. Non-infarcted tissue was stained red, whereas necrotic tissue remained unstained. The transverse sections were fixed with $10 \%$ formaldehyde and imaged. Images were captured using a digital camera and were transferred to a computer for subsequent management with Photoshop CS2 software (Adobe Systems, San Jose, CA, USA).

$L D H$. Myocardial tissue damage was assessed by determining the LDH activity in the coronary effluent collected at the end of stabilization, 3 and $4 \mathrm{~h}$ after the induction of ischemia. The activity of LDH was measured following the manufacturer's instructions (Nanjing Jiancheng Bioengineering Institute).

Ultrastructural changes to mitochondria in myocardial cells. Following $4 \mathrm{~h}$ of ischemia, the hearts were rapidly excised. Transmural tissue samples $\left(1 \mathrm{~mm}^{3}\right)$ were obtained from the left anterior myocardium and immediately immersed in ice-cold $4 \%, 0.1 \mathrm{~mol} / \mathrm{l}$ phosphate-buffered glutaraldehyde ( $\mathrm{pH}$ 7.2). The 
Table I. Effect of hydrogen sulfide on the cardiac function in rats following ischemia.

\begin{tabular}{lcccc}
\hline Group & LVDP $(\mathrm{mmHg})$ & $+\mathrm{dP}^{2} \mathrm{dt}_{\max }(\mathrm{mmHg} / \mathrm{sec})$ & $-\mathrm{dP} / \mathrm{dt}_{\max }(\mathrm{mmHg} / \mathrm{sec})$ & $\mathrm{CF}(\mathrm{ml} / \mathrm{min})$ \\
\hline Sham & $63.12 \pm 1.46$ & $3189 \pm 189$ & $1762 \pm 122$ & $3.65 \pm 0.12$ \\
Model & $43.27 \pm 3.01^{\mathrm{a}}$ & $1174 \pm 79^{\mathrm{a}}$ & $861 \pm 54^{\mathrm{a}}$ & $2.15 \pm 0.21^{\mathrm{a}}$ \\
I+L NaHS & $49.77 \pm 2.07^{\mathrm{b}}$ & $1724 \pm 126^{\mathrm{b}}$ & $1066 \pm 38^{\mathrm{b}}$ & $2.29 \pm 0.08^{\mathrm{c}}$ \\
I+M NaHS & $55.50 \pm 1.60^{\mathrm{b}}$ & $2298 \pm 167^{\mathrm{b}}$ & $1278 \pm 45^{\mathrm{b}}$ & $2.95 \pm 0.12^{\mathrm{b}}$ \\
I+H NaHS & $61.75 \pm 1.67^{\mathrm{b}}$ & $2844 \pm 139^{\mathrm{b}}$ & $1587 \pm 43^{\mathrm{b}}$ & $3.36 \pm 0.11^{\mathrm{b}}$ \\
\hline
\end{tabular}

Hearts were treated with normal perfusate or NaHS at concentrations of 5, 10 or $20 \mu \mathrm{mol} / 12 \mathrm{~h}$ after ischemia. The hemodynamic parameters were measured $4 \mathrm{~h}$ after ischemia. Data are presented as the mean \pm standard error of the mean ( $\mathrm{n}=8 \mathrm{rats}$ in each group). ${ }^{\mathrm{a}} \mathrm{P}<0.01 \mathrm{vs}$. the sham group; ${ }^{\mathrm{b}} \mathrm{P}<0.01$ and ${ }^{\mathrm{C}} \mathrm{P}<0.01$ vs. the model group. LVDP, left ventricular developed pressure; $+\mathrm{dp} / \mathrm{dt}_{\max }$, maximum velocity of left ventricular systolic pressure; - $\mathrm{dp}_{\mathrm{dt}} \mathrm{dax}_{\max }$, maximum velocity of left ventricular diastolic pressure; $\mathrm{CF}$, coronary flow rate; I+LNaHS, infarct plus low-dose NaHS; I+MNaHS, infarct plus middle-dose NaHS; I+HNaHS, infarct plus high-dose NaHS.

tissues were washed twice in dimethyl arsenate buffer and the tissue blocks were then postfixed for $2 \mathrm{~h}$ in $1 \%, 0.1 \mathrm{~mol} / \mathrm{l}$ phosphate-buffered $\mathrm{OsO}_{4}(\mathrm{pH}$ 7.2). This was followed by a further two washes in dimethyl arsenate buffer and dehydration. The tissues were subsequently embedded in araldite. Ultra-thin sections were cut and double stained in uranyl acetate and lead citrate. The sections were observed under a transmission electron microscope to assess the ultrastructural features of the cardiomyocytes.

Isolated mitochondria. Mitochondria were isolated from the adult rat hearts by homogenization and differential centrifugation, as described previously (30). Briefly, the heart was rapidly excised and washed in buffer containing $70 \mathrm{mM}$ sucrose, $210 \mathrm{mM}$ mannitol, $1 \mathrm{mM}$ EDTA and $50 \mathrm{mM}$ Tris (pH 7.4) at $4^{\circ} \mathrm{C}$. Following changes of buffer, the cardiac samples were cut into small pieces and homogenized. The homogenate was centrifuged at $1,300 \mathrm{x}$ g for $3 \mathrm{~min}$ at $2^{\circ} \mathrm{C}$. The supernatant was then collected and re-centrifuged at $10,000 \mathrm{x} \mathrm{g}$ for $8 \mathrm{~min}$ at $2{ }^{\circ} \mathrm{C}$. The pellet was resuspended in EDTA-free homogenization buffer [70 mM sucrose, $210 \mathrm{mM}$ mannitol ( $\mathrm{pH} 7.4$ ) with $50 \mathrm{mM}$ Tris] and centrifuged at $10,000 \mathrm{x} \mathrm{g}$ for $10 \mathrm{~min}$ at $2^{\circ} \mathrm{C}$. The prepared mitochondria were diluted in isolation medium prior to use.

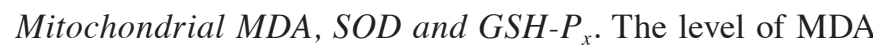
and the activities of SOD and GSH-P ${ }_{\mathrm{x}}$ were determined using reagent kits, in accordance with the manufacturer's instructions (Nanjing Jiancheng Bioengineering Institute).

Statistical analysis. Results are presented as the mean \pm standard error of the mean. All tests were performed using SPSS 13.0 (SPSS, Inc., Armonk, NY, USA). Data were analyzed using one-way analysis of variance followed by Tukey's post hoc multiple comparison test. $\mathrm{P}<0.05$ was considered to indicate a statistically significant difference.

\section{Results}

Effect of $\mathrm{H}_{2} \mathrm{~S}$ on cardiac function during ischemia. The cardiodynamic variables are shown in Table I. Subsequent to myocardial ischemia injury, the values for left ventricular developed pressure (LVDP), $\pm \mathrm{dP} / \mathrm{dt}_{\max }$ and CF were significantly decreased in the model group relative to those in the sham group $(\mathrm{P}<0.01)$, whilst these parameters showed significant increases in the NaHS low-, middle- and high-dose groups as compared with those in the model group $(\mathrm{P}<0.05$ or $\mathrm{P}<0.01)$.

Changes in $\mathrm{H}_{2}$ S content and CSE activity in myocardial tissue. The content of $\mathrm{H}_{2} \mathrm{~S}$ and the activity of CSE in cardiac tissue were significantly decreased in the model group as compared with those in the sham group $(\mathrm{P}<0.01$, Fig. 1). However, these parameters showed significant increases in the NaHS low-, middle- and high-dose groups compared with those in the model group $(\mathrm{P}<0.05$ or $\mathrm{P}<0.01$, Fig. 1).

Effect of $\mathrm{H}_{2} \mathrm{~S}$ on infarct size. The myocardial infarct volume was significantly increased in the model group compared with that of the sham group ( $\mathrm{P}<0.01$, Fig. 2). No significant differences were observed in myocardial infarct volume between the NaHS low-dose group and the model group, whereas the infarct volumes were significantly decreased in the NaHS middle- and high-dose groups as compared with those in the model group $(\mathrm{P}<0.01$, Fig. 2).

Effect of $\mathrm{H}_{2} \mathrm{~S}$ on LDH activity. No statistically significant differences were observed in the activity of $\mathrm{LDH}$ in the perfusate among the experimental groups prior to ischemia (Table II). The activity of LDH in the perfusate was significantly increased in the model group compared with that of the sham group $(\mathrm{P}<0.01$, Table II). However, the activity of $\mathrm{LDH}$ in the perfusate was significantly decreased in NaHS low-, middle- and high-dose groups compared with that in the model group $(\mathrm{P}<0.01$, Table II).

Effect of $\mathrm{H}_{2} \mathrm{~S}$ on the ultrastructure of mitochondria in myocardial cells. In the sham group, the ultrastructure of the myocardial cells exhibited regular mitochondria with uniform size, complete mitochondrial cristae and an intact nuclear membrane. In the model group, the myocardial cells were characterized by mitochondrial swelling, disappearance or deformation of mitochondrial cristae, disruption of the nuclear membrane and nuclear condensation. The NaHS low-, 
Table II. Effect of hydrogen sulfide on the activity of LDH in the coronary effluent of each group.

\begin{tabular}{lrrr}
\hline & \multicolumn{2}{c}{ LDH activity (U/l) } \\
\cline { 2 - 4 } Group & BS 20 min & Ischemia 3 h & Ischemia 4 h \\
\hline Sham & $11.18 \pm 0.42$ & $31.46 \pm 3.97$ & $49.68 \pm 3.06$ \\
Model & $11.24 \pm 0.38$ & $82.35 \pm 4.43^{\mathrm{a}}$ & $103.94 \pm 6.22^{\mathrm{a}}$ \\
I+L NaHS & $11.20 \pm 0.38$ & $66.02 \pm 3.69^{\mathrm{b}}$ & $83.49 \pm 3.36^{\mathrm{b}}$ \\
I+M NaHS & $11.22 \pm 0.35$ & $51.32 \pm 4.16^{\mathrm{b}}$ & $70.39 \pm 4.07^{\mathrm{b}}$ \\
I + H NaHS & $11.17 \pm 0.42$ & $44.28 \pm 2.52^{\mathrm{b}}$ & $60.45 \pm 3.89^{\mathrm{b}}$ \\
\hline
\end{tabular}

Hearts were treated with normal perfusate or NaHS at concentrations of 5,10 or $20 \mu \mathrm{mol} / 12 \mathrm{~h}$ after ischemia. The activity of LDH in cardiac tissue was measured prior to ischemia and 3 and $4 \mathrm{~h}$ after ischemia. Data are presented as the mean \pm standard error of the mean (n=8 rats in each group). ${ }^{a} \mathrm{P}<0.01$ vs. the sham group; ${ }^{\mathrm{P}}<0.01$ vs. the model group. I+LNaHS, infarct plus low-dose NaHS; I+MNaHS, infarct plus middle-dose NaHS; I+HNaHS, infarct plus high-dose NaHS; LDH, lactate dehydrogenase; BS, balance perfusion.

A

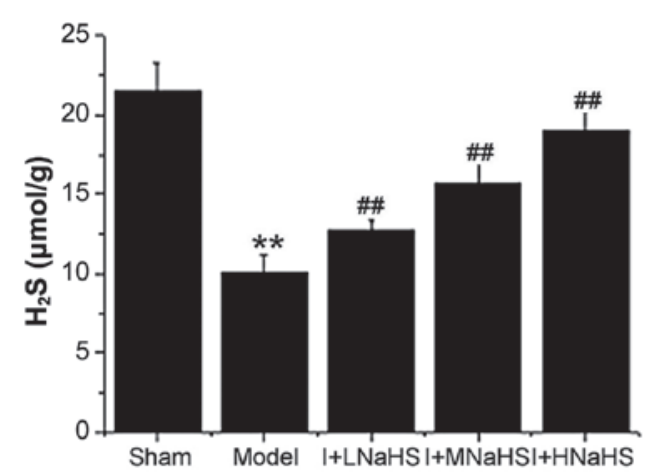

B

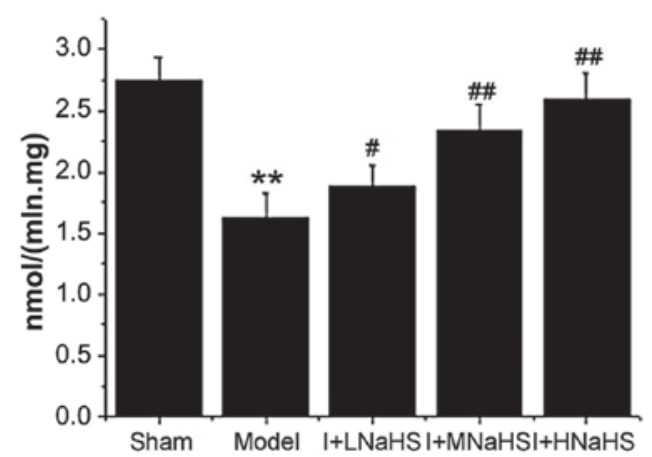

Figure 1. Changes in the content of $\mathrm{H}_{2} \mathrm{~S}$ and the activity of CSE in cardiac tissue following ischemia. Hearts were treated with normal perfusate or NaHS at concentrations of 5,10 or $20 \mu \mathrm{M} 2 \mathrm{~h}$ after ischemia. (A) The content of $\mathrm{H}_{2} \mathrm{~S}$ in the cardiac tissue and (B) the activity of CSE were measured $4 \mathrm{~h}$ after ischemia. Data are presented as the mean \pm standard error of the mean ( $\mathrm{n}=8$ rats in each group). ${ }^{* *} \mathrm{P}<0.01$ vs. the sham group; ${ }^{\#} \mathrm{P}<0.05$ and ${ }^{\# \#} \mathrm{P}<0.01$ vs. the model group. I+LNaHS, infarct plus low-dose NaHS; I+MNaHS, infarct plus middle-dose NaHS; I+HNaHS, infarct plus high-dose NaHS; $\mathrm{H}_{2} \mathrm{~S}$, hydrogen sulfide; CSE, cystathione- $\gamma$-lyase.

middle- and high-dose groups showed less significant pathological changes in the myofilaments, mitochondria and nuclei as compared with the model group (Fig. 3).

Effects of $\mathrm{H}_{2} \mathrm{~S}$ on mitochondrial MDA content and SOD and glutathione GSH-P $P_{x}$ activity. The content of MDA in the cardiac mitochondria was significantly increased and the activities of SOD and GSH-P $\mathrm{P}_{\mathrm{x}}$ were significantly decreased
A

Sham

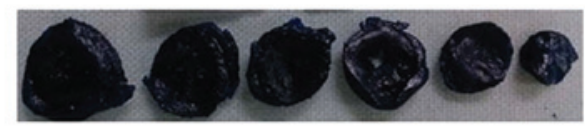

Model

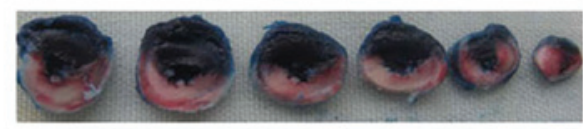

$\mathrm{H}-\mathrm{NaHS}$

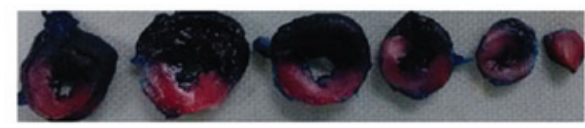

M-NaHS

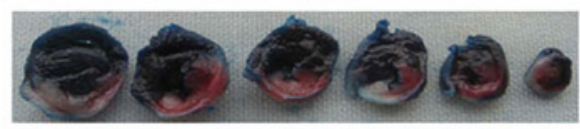

\section{L-NaHS}

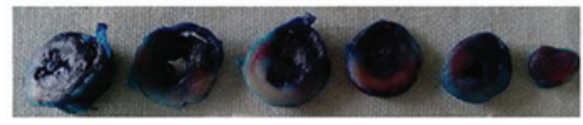

B

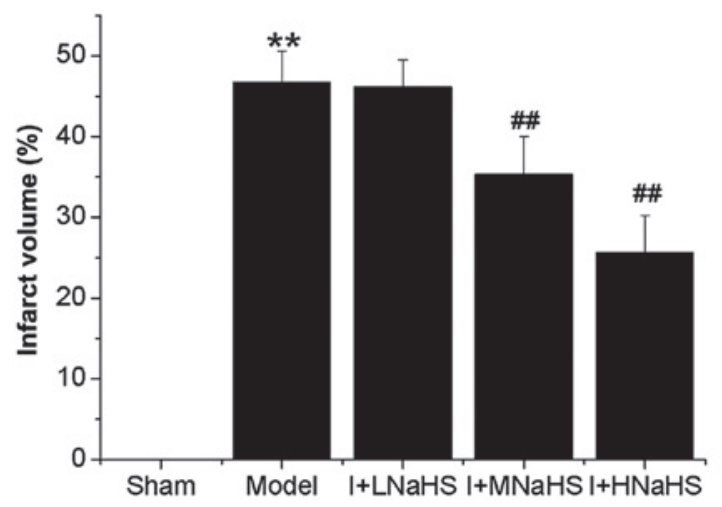

Figure 2. Effect of $\mathrm{H}_{2} \mathrm{~S}$ on the infarct volume following ischemia. Hearts were treated with normal perfusate or NaHS at concentrations of 5, 10 or $20 \mu \mathrm{M} 2 \mathrm{~h}$ after ischemia. (A) Representative images of infarct volume in each group. (B) Quantification of the effect of $\mathrm{H}_{2} \mathrm{~S}$ on infarct volume (expressed as a percentage of total volume). Data are presented as the mean \pm standard error of the mean ( $\mathrm{n}=8$ rats in each group). ${ }^{* *} \mathrm{P}<0.01 \mathrm{vs}$. the sham group; ${ }^{\# \#} \mathrm{P}<0.01$ vs. the model group. I+LNaHS, infarct plus low-dose NaHS; I+MNaHS, infarct plus middle-dose NaHS; I+HNaHS, infarct plus high-dose NaHS; $\mathrm{H}_{2} \mathrm{~S}$, hydrogen sulfide.

in the model group compared with those in the sham group $(\mathrm{P}<0.01$, Fig. 4). By contrast, the content of MDA was signifi- 


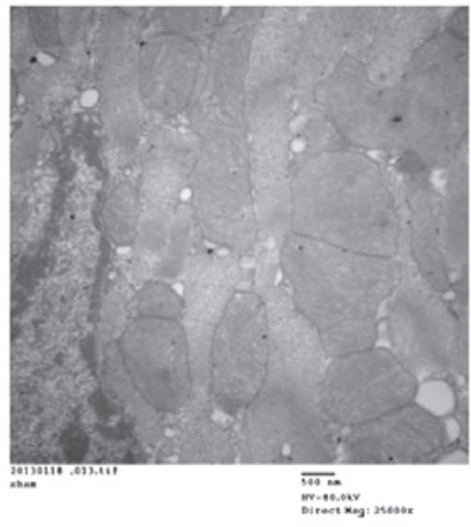

Sham

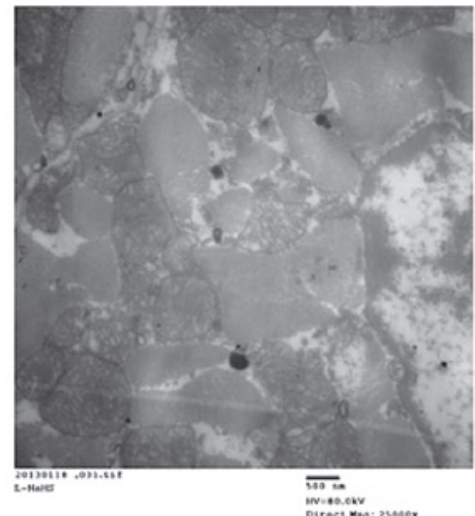

I+LNaHS

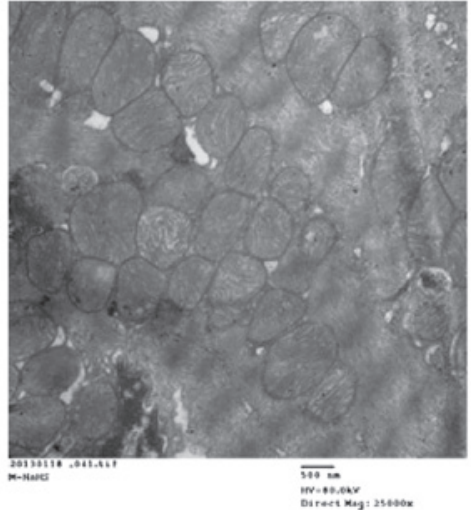

I+MNaHS

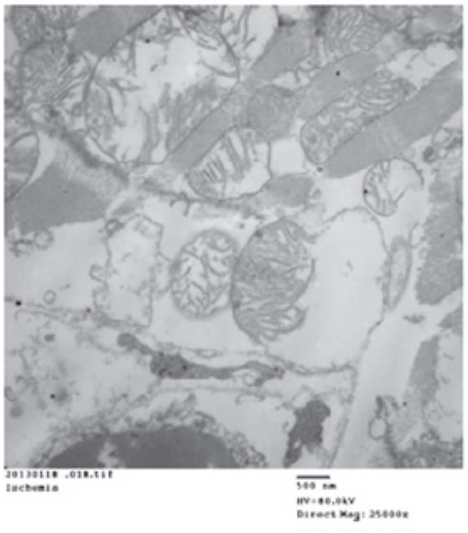

Model

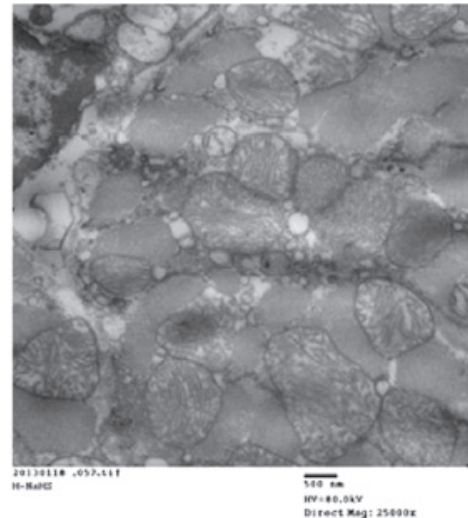

$\mathrm{I}+\mathrm{H} \mathrm{NaHS}$

Figure 3. Pathological changes in the ultrastructure of myocardium, observed using electron microscopy. Hearts were treated with normal perfusate or NaHS at concentrations of 5,10 or $20 \mu \mathrm{mol} / 12 \mathrm{~h}$ after ischemia (magnification, x25,000). I+LNaHS, infarct plus low-dose NaHS; I+MNaHS, infarct plus middle-dose NaHS; I+HNaHS, infarct plus high-dose NaHS.
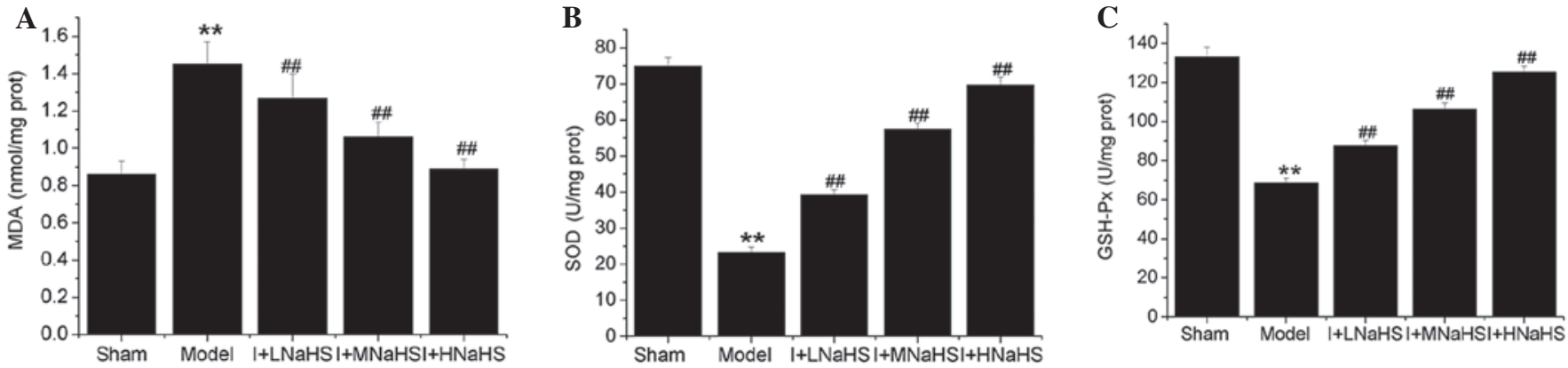

Figure 4. Effect of hydrogen sulfide on the antioxidative activities in the mitochondria of cardiomyocytes in isolated ischemic rat hearts. Hearts were treated with normal perfusate or NaHS at concentrations of 5,10 or $20 \mu \mathrm{mol} / 12 \mathrm{~h}$ after ischemia. (A) MDA content, (B) SOD activity and (C) GSH-P $\mathrm{x}_{\mathrm{activity}}$ in the different groups. Data are presented as the mean \pm standard error of the mean ( $\mathrm{n}=8$ rats in each group). ${ }^{* *} \mathrm{P}<0.01$ vs. the sham group; ${ }^{\# \#} \mathrm{P}<0.01$ vs. the model group. I+LNaHS, infarct plus low-dose NaHS; I+MNaHS, infarct plus middle-dose NaHS; I+HNaHS, infarct plus high-dose NaHS; MDA, malondialdehyde; SOD, superoxide dismutase; GSH-P ${ }_{x}$, glutathione peroxidase.

cantly decreased and the activities of SOD and GSH-P $\mathrm{P}_{\mathrm{x}}$ were significantly increased in the cardiac mitochondria in the NaHS low-, middle- and high-dose groups compared with those in the model group ( $\mathrm{P}<0.01$, Fig. 4$)$.

\section{Discussion}

It has been shown $\mathrm{H}_{2} \mathrm{~S}$ is a novel gasotransmitter produced in numerous mammalian cells and tissues (31-33). $\mathrm{H}_{2} \mathrm{~S}$ is gener- ated primarily from L-cysteine by CSE in the cardiovascular system (11,34,35); CSE activity has been detected in the heart (32) and vascular smooth muscle (36). There is a growing evidence to suggest that there are correlations among CSE activity, $\mathrm{H}_{2} \mathrm{~S}$ concentration and cardiovascular disease (37-40).

It has been suggested that $\mathrm{H}_{2} \mathrm{~S}$ exerts antioxidant, anti-inflammatory, and anti-apoptotic effects $(41,42) . \mathrm{H}_{2} \mathrm{~S}$ has been shown to inhibit lipid peroxidation during heart ischemia-reperfusion and to decrease the ischemia-induced 
death of myocardial cells via an oxygen free radical-reducing mechanism (42). This suggests that $\mathrm{H}_{2} \mathrm{~S}$ may act as an important modulator in cardiovascular physiology and pathophysiology. Since the role of $\mathrm{H}_{2} \mathrm{~S}$ in the pathogenesis of ligature-induced regional myocardial ischemia has not been investigated in vitro, to the best of our knowledge, the present study demonstrated for the first time the role of $\mathrm{H}_{2} \mathrm{~S}$ in a ligature-induced myocardial ischemia injury model in rats in vitro. An isolated rat heart model was used such that extrinsic humoral and autonomic nervous system influences, in addition to the effect of $\mathrm{H}_{2} \mathrm{~S}$ on peripheral vascular tone, could be excluded (43).

In our previous study, comparisons with the sham group revealed that the LVDP, $\pm \mathrm{dP} / \mathrm{dt}_{\max }$ and $\mathrm{CF}$ were significantly decreased in the ischemia group at 30 min and 1, 2, 3 and $4 \mathrm{~h}$ after ischemia and that the infarct volumes in the ischemia group were markedly increased between 1 and $4 \mathrm{~h}$ after ischemia. Associated with these injuries, the content of $\mathrm{H}_{2} \mathrm{~S}$ and the activity of CSE in the cardiac tissue were significantly decreased compared with those of the sham control group during the 1-4 $\mathrm{h}$ after ischemia. These data revealed that the $\mathrm{CSE} / \mathrm{H}_{2} \mathrm{~S}$ pathway may participate in the pathophysiological regulation of myocardial ischemia injury in isolated rat hearts. The CSE activity is dependent on pyridoxal 5'-phosphate (PLP), which is reduced in ischemic disease, such as stroke (44). Low PLP levels may inhibit the CSE activity and lead to decreased myocardial and plasma $\mathrm{H}_{2} \mathrm{~S}$ generation. Furthermore, CSE inhibition may decrease glutathione levels (45), and this reduction may explain the increase in infarct size (46).

The cardiodynamic parameters and myocardial infarction volume were selected as the parameters to assess the functional performance of the isolated rat heart following ischemia. To explore the effects of $\mathrm{H}_{2} \mathrm{~S}$ on regional myocardial ischemia injury, the isolated rat heart was treated with NaHS following the induction of ischemia. NaHS has a fast releasing rate in aqueous solution, producing one-third $\mathrm{H}_{2} \mathrm{~S}$ as compared with the concentration of the salt $(47,48)$, without changing the $\mathrm{pH}$ of the medium (49). In the present study, the content of $\mathrm{H}_{2} \mathrm{~S}$ and the activity of CSE in the cardiac tissue were significantly decreased in the model group as compared with those in the sham group. By contrast, the content of $\mathrm{H}_{2} \mathrm{~S}$ and the activity of CSE in the cardiac tissue were significantly increased in the NaHS low-, middle- and high-dose groups as compared with those in the model group. The LVDP, $\pm \mathrm{dP} / \mathrm{dt}_{\max }$ and CF were significantly increased in the NaHS low-, middle- and high-dose groups as compared with those in the model group. The infarct volume is strongly associated with the prognosis of acute myocardial infarction and negatively correlated with improvements in the cardiodynamic parameters. In particular, impairments in the cardiac contractility become increasingly severe with increasing infarct volume; therefore, a decrease in infarct volume may be a useful parameter for the evaluation of the effectiveness of anti-myocardial ischemia drugs (50). In the present study, the infarct volumes were significantly decreased in NaHS middle- and high-dose groups compared with those in the model group. Taken together, these data demonstrate that $\mathrm{H}_{2} \mathrm{~S}$ exerts protective effects against myocardial ischemia injury in isolated rat hearts. Similar to $\mathrm{NO}, \mathrm{H}_{2} \mathrm{~S}$ has been found to be a vasodilatory agent that acts through alterations in $\mathrm{K}^{+}$ channel activity and elevated cyclic guanosine monophosphate levels in vascular smooth muscle cells $(51,52)$. Consistent with these observations, our findings revealed that reduced levels of $\mathrm{H}_{2} \mathrm{~S}$ are associated with the constriction of blood vessels. Furthermore, the vasodilatory effects of NaHS can dilate coronary arteries and increase $\mathrm{CF}$ in ischemic diseases, thereby reducing ischemia-induced cellular damage.

Mitochondrial ultrastructural (53) and functional (54) injury occurs early and progresses through the course of ischemia $(54,55)$. Mitochondrial damage results in a loss of mitochondrial function, impairing energy production and cell physiology, and an enhancement of pathological function, producing oxidative-, calcium- and apoptosis-mediated myocyte injury (56). Mitochondrial oxidative damage participates in a variety of pathologies, including cardiovascular disorders and neurodegenerative diseases. As such, the protection of mitochondria from oxidative damage may be an effective therapeutic strategy. The effect of $\mathrm{H}_{2} \mathrm{~S}$ on myocardial oxidative stress following ischemia was therefore assessed in the present study. The production of reactive oxygen species by mitochondria leads to the formation of lipid peroxidation products and, in turn, can induce oxidative stress, thereby causing cellular and mitochondrial damage $(57,58)$. The release of free radicals, coupled with the ischemia-induced decrease in antioxidant activity, leaves the myocardium susceptible to injury. It has been observed that phospholipid peroxidation and subsequent damage to complex I jointly increase membrane leakage, mitochondrial swelling, cytochrome $c$ release and caspase activation, resulting in cell death (59). The leakage of the cytosolic enzyme LDH is correlated with a loss of cell membrane integrity, and measuring the change in MDA content indicates the degree of damage caused by membrane lipid peroxidation. In this study, lipid peroxidation was observed to increase in the heart upon ligation of the LAD coronary artery. This was apparent through increases in the MDA content and $\mathrm{LDH}$ level relative to the sham group. However, the addition of NaHS significantly decreased the MDA content and LDH level. This result is consistent with the findings on the effects of $\mathrm{H}_{2} \mathrm{~S}$ on a rat model of myocardial infarction in vivo (60). In the majority of mammalian species, SOD and GSH-P ${ }_{x}$ appear to be the most active antioxidant enzymes in the myocardium to provide defense for cellular organelles against oxidative damage caused by reactive oxygen species (61). In the present study, NaHS administration significantly increased the activities of SOD and GSH-P $\mathrm{P}_{\mathrm{x}}$ in the cardiac mitochondria following ischemia. These data demonstrate that treatment with NaHS enhances the capacity of antioxidant enzymes, and the underlying mechanism of action is attributed to the protective effects exerted against the oxidative stress-mediated injury in the mitochondria. Transmission electron microscopy revealed a marked relief in mitochondrial swelling and increased matrix density in isolated ischemic rat hearts receiving NaHS, further suggesting a role for the preservation of mitochondrial function in the observed cytoprotection.

In conclusion, the pathophysiological process of ligature-induced regional myocardial ischemia injury is associated with the impaired endogenous $\mathrm{CSE} / \mathrm{H}_{2} \mathrm{~S}$ pathway. Exogenously administered $\mathrm{H}_{2} \mathrm{~S}$ via NaHS can effectively protect myocytes and contractile activity and limit the extent of myocardial infarction. These protective effects of $\mathrm{H}_{2} \mathrm{~S}$ against myocardial ischemia injury appear to be mediated by its antioxidant activities and preservation of mitochondrial 
function. Taken together, these data strengthen evidence that $\mathrm{H}_{2} \mathrm{~S}$ may be a cardiovascular protective regulator for preventing or treating cardiovascular diseases. However, the exact mechanisms underlying the action of $\mathrm{H}_{2} \mathrm{~S}$ require further investigation.

\section{Acknowledgements}

This study was supported by the Natural Science Foundation of Hebei Province (C2009001458) and the Key Basic Research Program of Hebei Provincial Science and Technology Department (13967602D).

\section{References}

1. Thom T, Haase N, Rosamond W, et al; American Heart Association Statistics Committee and Stroke Statistics Subcommittee: Heart disease and stroke statistics - 2006 update: a report from the American Heart Association Statistics Committee and Stroke Statistics Subcommittee. Circulation 113: e85-e151, 2006.

2. Nabel EG and Braunwald E: A tale of coronary artery disease and myocardial infarction. N Engl J Med 366: 54-63, 2012.

3. Mathers CD and Loncar D: Projections of global mortality and burden of disease from 2002 to 2030. PLoS Med 3: e422, 2006.

4. Lloyd-Jones D, Adams RJ, Brown TM, et al; American Heart Association Statistics Committee and Stroke Statistics Subcommittee: Heart disease and stroke statistics - 2010 update: a report from the American Heart Association. Circulation 121: e46-e215, 2010.

5. Renda G and de Caterina R: Impact of antiplatelet therapy in heart disease. Adv Cardiol 47: 5-19, 2012.

6. Gnecchi M, Danieli P and Cervio E: Mesenchymal stem cell therapy for heart disease. Vascul Pharmacol 57: 48-55, 2012.

7. Songco AV and Brener SJ: Initial strategy of revascularization versus optimal medical therapy for improving outcomes in ischemic heart disease: a review of the literature. Curr Cardiol Rep 14: 397-407, 2012.

8. Bhind R, Witting PK, McMahon AC, Khachigian LM and Lowe HC: Rat models of myocardial infarction. Pathogenetic insights and clinical relevance. Thromb Haemost 96: 602-610, 2006.

9. Langendorff O: Untersuchungen am überlebenden Säugethierherzen. Arch Ges Physiol 61: 291-332, 1895.

10. Skrzypiec-Spring M, Grotthus B, Szelag A and Schulz R: Isolated heart perfusion according to Langendorff - still viable in the new millennium. J Pharmacol Toxicol Methods 55: 113-126, 2007.

11. Wang R: Two's company, three's a crowd: can $\mathrm{H}_{2} \mathrm{~S}$ be the third endogenous gaseous transmitter? FASEB J 16: 1792-1798, 2002.

12. Ignarro LJ, Buga GM, Wood KS, Byrns RE and Chaudhuri G: Endothelium-derived relaxing factor produced and released from artery and vein is nitric oxide. Proc Natl Acad Sci USA 84: 9265-9269, 1987.

13. Palmer RM, Ferrige AG, Moncada S: Nitric oxide release accounts for the biological activity of endothelium derived relaxing factor. Nature 327: 524-526, 1987.

14. Marks GS, Brien JF, Nakatsu K, et al: Does carbon monoxide have a physiological function? Trends Pharmacol Sci 12: 185-188, 1991

15. Verma A, Hirsch DJ, Glatt CE, et al: Carbon monoxide: a putative neural messenger. Science 259: 381-384, 1993.

16. Abe K and Kimura H: The possible role of hydrogen sulfide as an endogenous neuromodulator. J Neurosci 16: 1066-1071, 1996.

17. Pearson RJ, Wilson T and Wang R: Endogenous hydrogen sulfide and the cardiovascular system-what's the smell all about? Clin Invest Med 29: 146-150, 2006.

18. Szabó C: Hydrogen sulphide and its therapeutic potential. Nat Rev Drug Discov 6: 917-935, 2007.

19. Jha S, Calvert JW, Duranski MR, Ramachandran A and Lefer DJ: Hydrogen sulfide attenuates hepatic ischemia-reperfusion injury: role of antioxidant and antiapoptotic signaling. Am J Physiol Heart Circ Physiol 295: H801-H806, 2008.

20. Bos EM, Leuvenink HG, Snijder PM, et al: Hydrogen sulfide-induced hypometabolism prevents renal ischemia/reperfusion injury. J Am Soc Nephrol 20: 1901-1905, 2009.

21. Wang MJ, Cai WJ, Li N, Ding YJ, Chen Y and Zhu YC: The hydrogen sulfide donor NaHS promotes angiogenesis in a rat model of hind limb ischemia. Antioxid Redox Signal 12: 1065-1077, 2010
22. Zhang Z, Huang H, Liu P, Tang C and Wang J: Hydrogen sulfide contributes to cardioprotection during ischemia-reperfusion injury by opening K ATP channels. Can J Physiol Pharmacol 85: $1248-1253,2007$

23. Ji Y, Pang QF, Xu G, Wang L, Wang JK and Zeng YM: Exogenous hydrogen sulfide postconditioning protects isolated rat hearts against ischemia-reperfusion injury. Eur J Pharmacol 587: 1-7, 2008.

24. Sodha NR, Clements RT, Feng J, et al: The effects of therapeutic sulfide on myocardial apoptosis in response to ischemia-reperfusion injury. Eur J Cardiothorac Surg 33: 906-913, 2008.

25. Sivarajah A, Collino M, Yasin M, et al: Anti-apoptotic and anti-inflammatory effects of hydrogen sulfide in a rat model of regional myocardial I/R. Shock 31: 267-274, 2009.

26. Lavu M, Bhushan S and Lefer DJ: Hydrogen sulfide-mediated cardioprotection: mechanisms and therapeutic potential. Clin Sci (Lond) 120: 219-229, 2011.

27. Liu H, Yan J, Xu YW, Bai XJ and Wu BW: Modification of ex-vivo ischemia/reperfusion modeling in isolated rat heart. Chinese Remedies \& Clinics 7: 586-587, 2007 (In Chinese).

28. Stipanuk MH and Beck PW: Characterization of the enzymic capacity for cysteine desulphhydration in liver and kidney of the rat. Biochem J 206: 267-277, 1982

29. Hwa JS, Jin YC, Lee YS, et al: 2-methoxycinnamaldehyde from Cinnamomum cassia reduces rat myocardial ischemia and reperfusion injury in vivo due to $\mathrm{HO}-1$ induction. J Ethnopharmacol 139: 605-615, 2012.

30. Shiva S, Brookes PS and Darley-Usmar VM: Methods for measuring the regulation of respiration by nitric oxide. Methods Cell Biol 80: 395-416, 2007.

31. Abe K and Kimura H: The possible role of hydrogen sulfide as an endogenous neuromodulator. J Neurosci 16: 1066-1071, 1996.

32. Geng B, Yang J, Qi Y, Zhao J, Pang Y, Du J and Tang C: $\mathrm{H}_{2} \mathrm{~S}$ generated by heart in rat and its effects on cardiac function. Biochem Biophys Res Commun 313: 362-368, 2004.

33. Li L, Rose P and Moore PK: Hydrogen sulfide and cell signaling. Annu Rev Pharmacol Toxicol 51: 169-187, 2011.

34. Chen P, Poddar R, Tipa EV, et al: Homocysteine metabolism in cardiovascular cells and tissues: implications for hyperhomocysteinemia and cardiovascular disease. Adv Enzyme Regul 39: 93-109, 1999.

35. Szabó C: Hydrogen sulphide and its therapeutic potential. Nat Rev Drug Discov 6: 917-935, 2007.

36. Zhao W, Zhang J, Lu Y and Wang R: The vasorelaxant effect of $\mathrm{H}(2) \mathrm{S}$ as a novel endogenous gaseous K(ATP) channel opener. EMBO J 20: 6008-6016, 2001.

37. Geng B, Chang L, Pan C, et al: Endogenous hydrogen sulfide regulation of myocardial injury induced by isoproterenol. Biochem Biophys Res Commun 318: 756-763, 2004.

38. Jiang HL, Wu HC, Li ZL, Geng B and Tang CS: Changes of the new gaseous transmitter $\mathrm{H}_{2} \mathrm{~S}$ in patients with coronary heart disease. Di Yi Jun Yi Da Xue Xue Bao 25: 951-954, 2005 (In Chinese).

39. Bian JS, Yong QC, Pan TT, Feng ZN, Ali MY, Zhou S and Moore PK: Role of hydrogen sulfide in the cardioprotection caused by ischemic preconditioning in the rat heart and cardiac myocytes. J Pharmacol Exp Ther 316: 670-678, 2006.

40. Yong QC, Pan TT, Hu LF and Bian JS: Negative regulation of beta-adrenergic function by hydrogen sulphide in the rat hearts. J Mol Cell Cardiol 44: 701-710, 2008.

41. Tokuda K, Kida K, Marutani E, et al: Inhaled hydrogen sulfide prevents endotoxin-induced systemic inflammation and improves survival by altering sulfide metabolism in mice. Antioxid Redox Signal 17: 11-21, 2012.

42. Jiang LH, Luo X, He WA, Huang XX and Cheng TT: Effects of exogenous hydrogen sulfide on apoptosis proteins and oxidative stress in the hippocampus of rats undergoing heroin withdrawal. Arch Pharm Res 34: 2155-2162, 2011.

43. Ytrehus K: The ischemic heart - experimental models. Pharmacol Res 42: 193-203, 2000.

44. Kelly PJ, Kistler JP, Shih VE, et al: Inflammation, homocysteine, and vitamin B6 status after ischemic stroke. Stroke 35: 12-15, 2004.

45. Diwakar $L$ and Ravindranath V: Inhibition of cystathionine-gamma-lyase leads to loss of glutathione and aggravation of mitochondrial dysfunction mediated by excitatory amino acid in the CNS. Neurochem Int 50: 418-426, 2007.

46. Blaustein A, Deneke SM, Stolz RI, Baxter D, Healey N and Fanburg BL: Myocardial glutathione depletion impairs recovery after short periods of ischemia. Circulation 80: 1449-1457, 1989. 
47. Dombkowski RA, Russell MJ and Olson KR: Hydrogen sulfide as an endogenous regulator of vascular smooth muscle tone in trout. Am J Physiol Regul Integr Comp Physiol 286: R678-R685, 2004.

48. Bian JS, Yong QC, Pan TT, Feng ZN, Ali MY, Zhou S and Moore PK: Role of hydrogen sulfide in the cardioprotection caused by ischemic preconditioning in the rat heart and cardiac myocytes. J Pharmacol Exp Ther 316: 670-678, 2006.

49. Hosoki R, Matsuki N and Kimura H: The possible role of hydrogen sulfide as an endogenous smooth muscle relaxant in synergy with nitric oxide. Biochem Biophys Res Commun 237: 527-531, 1997.

50. Nie LH, Zhou YZ, Ding J, et al: Effects of matrine on infarct size and ultramicrostructure in rats with acute myocardial ischemic injury. Ningxia Med J 33: 292-294, 2011 (In Chinese).

51. Yang GD, Wu LY, Jiang B, et al: $\mathrm{H}_{2} \mathrm{~S}$ as a physiologic vasorelaxant: hypertension in mice with deletion of cystathionine gamma-lyase. Science 322: 587-590, 2008.

52. Wang R: Hydrogen sulfide: a new EDRF. Kidney Int 76: 700-704, 2009 .

53. Murry CE, Richard VJ, Reimer KA and Jennings RB: Ischemic preconditioning slows energy metabolism and delays ultrastructural damage during a sustained ischemic episode. Circ Res 66: 913-931, 1990.

54. Flameng W, Andres J, Ferdinande P, Mattheussen $M$ and Van Belle H: Mitochondrial function in myocardial stunning. J Mol Cell Cardiol 23: 1-11, 1991.
55. Lesnefsky EJ, Tandler B, Ye J, Slabe TJ, Turkaly J and Hoppel CL: Myocardial ischemia decreases oxidative phosphorylation through cytochrome oxidase in subsarcolemmal mitochondria. Am J Physiol 273: H1544-H1554, 1997.

56. Lesnefsky EJ, Moghaddas S, Tandler B, Kerner J and Hoppel CL: Mitochondrial dysfunction in cardiac disease: ischemia - reperfusion, aging, and heart failure. J Mol Cell Cardiol 33: 1065-1089, 2001.

57. Lowell BB and Shulman GI: Mitochondrial dysfunction and type 2 diabetes. Science 307: 384-387, 2005.

58. Roden M: Muscle triglycerides and mitochondrial function: possible mechanisms for the development of type 2 diabetes. Int J Obes (Lond) 29 (Suppl 2): S111-S115, 2005.

59. Hardy L, Clark JB, Darley-Usmar VM, Smith DR and Stone D: Reoxygenation-dependent decrease in mitochondrial NADH:CoQ reductase (Complex I) activity in the hypoxic/reoxygenated rat heart. Biochem J 274: 133-137, 1991.

60. Liu F, Zhang JX, Li LF, Zhang QZ, Ding YY and Zhang XY: Effects of hydrogen sulfide on myocardial mitochondrial injury during acute myocardial ischemia in rats. Zhongguo Ying Yong Sheng Li Xue Za Zhi 27: 158-162, 2011 (In Chinese).

61. Crystal GJ, Malik G, Yoon SH and Kim SJ: Isoflurane late preconditioning against myocardial stunning is associated with enhanced antioxidant defenses. Acta Anaesthesiol Scand 56: 39-47, 2012. 